\title{
HUMAN DNA QUANTIFICATION IN THE STOOLS OF PATIENTS WITH COLORECTAL CANCER
}

\author{
Yolanda TEIXEIRA, Jacqueline Miranda LIMA, Maria Luiza Almeida Prado Oliveira SOUZA, \\ Pedro AGUIAR Jr, Tiago Donizetti SILVA and Nora Manoukian FORONES
}

\begin{abstract}
Background - Colorectal cancer is one of the main cause of cancer in the world. Colonoscopy is the best screen method, however the compliance is less than 50\%. Quantification of human DNA (hDNA) in the feces may be a possible screen non-invasive method that is a consequence of the high proliferation and exfoliation of cancer cells. Objective - To quantify the human DNA in the stools of patients with colorectal cancer or polyps. Methods - Fifty patients with CRC, 26 polyps and 53 with normal colonoscopy were included. Total and human DNA were analyzed from the frozen stools. Results - An increased concentration of hDNA in the stools was observed in colorectal cancer patients compared to controls and polyps. Tumors localized in the left side of the colon had higher concentrations of hDNA. There were no difference between polyps and controls. A cut off of $0.87 \mathrm{ng} / \mathrm{mL}$ of human DNA was determined for colorectal cancer patients by the ROC curve, with a sensitivity of $66 \%$ and a specificity of $86.8 \%$. For polyps the cut off was 0.41 , the sensitivity was $41 \%$ and the specificity $77.4 \%$. Conclusion - A higher concentration of hDNA had been found in colorectal cancer patients The quantification of hDNA from the stools can be a trial method for the diagnosis of colorectal cancer.
\end{abstract}

HEADINGS - Colorectal neoplasms, diagnosis. Polyps. DNA. Feces

\section{INTRODUCTION}

Colorectal cancer (CRC) is the second cause of cancer in the world, with 1,2 million new cases and 6400000 deaths yearly ${ }^{(9)}$. In the next decades, due to aging and population growth, the incidence of CRC tends to increase. The Brazilian National Institute of Cancer $^{(12)}$ estimated that 32,600 new cases were diagnosed and 14016 patients died from this disease last year ${ }^{(12)}$.

The high prevalence of CRC, the well-known natural history, the prevention by removal of adenomas and the possibility of cure at early detection are the criteria for screening recommendations ${ }^{(8,29)}$.

The Guaiac Fecal occult blood test (G-FOBT) is a low cost, non-invasive, and simple exam, with a low sensitivity that range between $30 \%$ and $50 \%$ for cancer diagnosis and $20 \%$ for polyps ${ }^{(25,26,27)}$. The Fecal Immunochemical Test (FIT), an immunochemical method detect 2.5 times more advanced adenomas and 2.5 more cancer compared to the FOBT ${ }^{(23)}$.
An Asian study with 7715 cases found 558 patients with positive and were referred for colonoscopy. Unfortunately only 149 did the exam. Among them only $4 \%$ had cancer and $23 \%$ had adenomas ${ }^{(22)}$. The authors believe that the small compliance to colonoscopy may be the cost of the exam or the accessibility to do in another hospital.

Colonoscopy is the gold standard method for colorectal screening, colon and rectum lesions may be diagnosed, mainly in the left colon, and the polyps may be removed ${ }^{(16)}$. However, colonoscopy is an invasive and expensive method with low adhesion. A recent study, did in Thailand, shown that asymptomatic patients preferred FIT, a noninvasive method, to colonoscopy ( $74.1 \%$ for FIT and 55.6\% for colonoscopy ${ }^{(19)}$.

Normal colonies of mucosal cells architecture maintain an intact crypt surface by a balance between programmed cell death and cell proliferation ${ }^{(20)}$. A cascade of genetic alterations occur on CRC carcinogenesis, breaking this balance, increasing 
proliferation and continuous exfoliation of cells with intact DNA compared to apoptotic cells ${ }^{(1,4)}$. The increase concentration of the human DNA (hDNA) in the feces of CRC patients allows the use of hDNA as a screening marker for $\mathrm{CRC}^{(2,30)}$.

Molecular tests on fecal DNA, analyzing genes mutations, epigenetic alterations or changes in the amount of DNA are being extensively evaluated as possible screening noninvasive methods ${ }^{(3)}$ to find potential markers of CRC and polyps.

A great problem in the study of DNA in the stools is the low concentration of hDNA compared to the total DNA (tDNA). This quantity represents about $0.01 \%$ of the total DNA. In cancer, due to the high cells proliferation, the quantification of hDNA increases and may be a screen method ${ }^{(2)}$.

The aim of the study was to quantify the total and human DNA in the stools of patients with CRC and compare to the stools of patients with polyps and controls.

\section{METHODS}

Patients with medical indication of colonoscopy at the Hospital Sao Paulo of the Federal University of Sao Paulo were included between March 2012 and March 2013. All of them collected stools at least 7 days before the exam and frozen them immediately. The patients were divided in 3 groups according to the result of colonoscopy in CRC, polyp or normal group. The patients were included independent of the sex, with a minimum age of 18 . Tumors localized on the caecum, ascendant or transverse colon were considered to be on the right side and the tumors localized on the descendent, sigmoid or rectum to be sited on the left. All the polyps were adenomas.

Patients with intestinal inflammatory disease and hyperplasic polyps were excluded.

The study was approved by a local Ethical Committee and all the patients were informed about the study and signed a consent term before giving the stool sample.

\section{DNA extraction}

Samples were taken from three different portions of the same stool specimen. DNA extraction was done using the commercial kit QiAmp DNA Stool mini Kit (Qiagen) according to the recommendation of the manufacturer. The total DNA was determined by ultraviolet absorbance at 260 $\mathrm{nm}$, using the Nanodrop 1000 (Thermo Scientific). DNA of each portion of the same sample were homogenized and the tests were done in duplicate.

The tDNA of the samples were quantified with a spectrophotometer with an absorbance of $260 \mathrm{~nm}$, with $1 \mu \mathrm{L}$ of the sample in each assay. The human DNA quantification was realized by PCR real time (qPCR) (StepOnePlus Real Time PCR System - Applied Biosystems) using a Quantifiler Human Srtandard kit (Applied Systems). It consists of a TaqMan probe with a fluorescence sign that identifies specific amplified products of human DNA.

\section{Statistical analysis}

Differences in sex between the two groups were determined by the chi-square test. The ANOVA test was used for the comparison of age, total fecal DNA and human fecal DNA between the groups. The association between the risk of developing cancer and the human DNA was assessed by calculating the odds ratio.

ROC (receiver-operating-characteristic) curves were constructed among the human DNA from CRC patients and controls as well for polyps and controls to determine the cut-off.

A $P$ value $<0.05$ was considered statistically significant.

\section{RESULTS}

A total of 129 patients were analyzed and divided in three groups: 53 individuals without cancer that constitutes the control group, 50 patients with colorectal cancer (CRC group) and 26 with adenomatous polyps (the polyp group).

Among the subjects 82 were females. There were no difference in gender $(P=0.112)$ or age $(P=0.632)$ between the groups. In the cancer group, one had stage I disease, 28 stage III, 6 stage IV. In 15 patients, the clinical stage were not determined because the patient did only the colonoscopy at the Hospital. The tumor were localized in the right colon in nine, in descendent or sigmoid in 18 and in the rectum in 23. For statistical purposes we grouped rectum, descendent and sigmoid.

All the polyps were adenoma with low or moderate dysplasia with an average size of $1.5 \mathrm{~cm}$ (range $0.5-3.0 \mathrm{~cm}$ ). Fifteen had one polyp, 10 had two polyps and only 1 had three polyps.

The mean tDNA stools and standard deviations (SD) of the patients with CRC were $88.47 \mathrm{ng} / \mu \mathrm{L}$ (56.45), of the control group $109.21 \mathrm{ng} / \mu \mathrm{L}$ (92.72) and of the polyp group $140.33 \mathrm{ng} / \mu \mathrm{L}$ (192.91). There were no difference between the groups $(P=0.15)($ Table 1$)$.

TABLE 1. Mean Total and human DNA in the three groups

\begin{tabular}{lcccc}
\hline & CRC & Polyps & Controls & \\
\hline & Mean \pm SD & Mean \pm SD & Mean \pm SD & \\
Variable & $(\eta \mathrm{g} / \mu \mathrm{L})$ & $(\eta \mathrm{g} / \mu \mathrm{L})$ & $(\eta \mathrm{g} / \mu \mathrm{L})$ & \\
& $88.4 \pm 56.4$ & $140.3 \pm .192 .2$ & $109.2 \pm 92,7$ & 0.15 \\
Total DNA & $16.8 \pm 31.9 \mathrm{a}$ & $1.24 \pm 3.86 \mathrm{~b}$ & $0.47 \pm 1.00 \mathrm{c}$ & 0.00 \\
Human DNA & & & &
\end{tabular}

In the study of hDNA, the mean DNA in the stools and the standard deviation (SD) of CRC patients was $16.82 \mathrm{ng} /$ $\mu \mathrm{L}$ (31.97), of the control group $0.47 \mathrm{ng} / \mu \mathrm{L}$ (1.00) and of the patients with polyps $1.24 \mathrm{ng} / \mu \mathrm{L}$ (3.86). There were no difference among controls and polyps $(P=0.17)$. The mean concentration of hDNA in the stools of the patients with CRC was higher compared to the controls $(P=0.001)$ or polyps $(P=0.001)$ (Table 1$)$. The hDNA was detected in all the faecal samples, but was significantly higher in the patients with colorectal cancer CRC (Figure 1). 


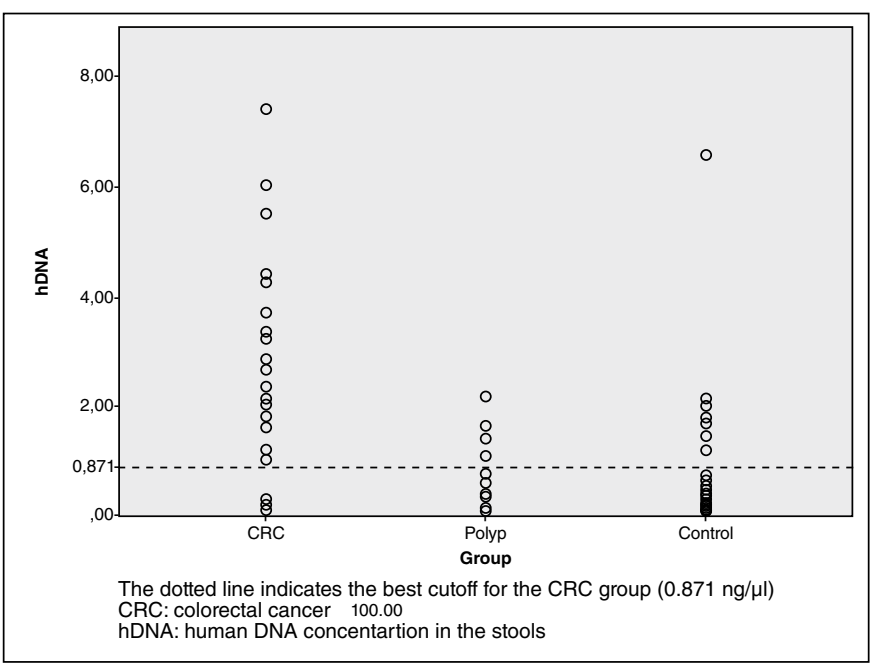

FIGURE 1. Human DNA concentration (ng/ $\mu \mathrm{l})$ on in the stools in CRC, polyps and controls

It has been observed an increased concentration of hDNA in tumors localized on the left $(20.26 \pm 34.40)$ compared to the others localized in the right $(1.10 \pm 2.41),(P=0.001)$. We did not observe an alteration in the quantity of hDNA in relation to the tumor invasion $(\mathrm{T} 1+\mathrm{T} 2+\mathrm{T} 3$ versus $\mathrm{T} 4$, $P=0.84$ ) (Table 2).

TABLE 2. Mean hDNA according to localization, tumor invsion and stage in the CRC group

\begin{tabular}{|c|c|c|}
\hline Tumor localization & $\begin{array}{c}\text { Mean } \pm \text { SD } \\
(\eta g / \mu L)\end{array}$ & $P$ \\
\hline Right $(\mathrm{n}=9)$ & $1.10 \pm 2.41$ & 0.001 \\
\hline Left $(n=41)$ & $20.2 \pm 34.4$ & \\
\hline \multicolumn{3}{|l|}{ Tumoral Invasion } \\
\hline $\mathrm{T} 1+\mathrm{T} 2+\mathrm{T} 3(\mathrm{n}=29)$ & $9.9 \pm 19.7$ & 0.84 \\
\hline T4 $(n=6)$ & $11.2 \pm 13.1$ & \\
\hline \multicolumn{3}{|l|}{ Tumor stage } \\
\hline 1,11 and $111(\mathrm{n}=31)$ & $8.55(16.8)$ & 0.247 \\
\hline IV $(n=4)$ & $19.8(24.4)$ & \\
\hline
\end{tabular}

The ROC curve stablished that the value of $0.678 \mathrm{ng} / \mu \mathrm{L}$ of hDNA was the best cut off for CRC diagnosis, with a sensibility of $66 \%$ and a specificity of $86.8 \%$ (IC $95 \%: 0.7-0.9$ ) (Table 2) and AUC of 0.87 (Figure 2). For the polyps group compared to the controls, the AUC was lower (AUC=0.6) (Figure 3), with a cut off of $0.41 \mathrm{ng} / \mu \mathrm{L}$, a sensitivity of $41 \%$ and a specificity of 78\% (IC 95\%: 0.47-0.73) (Table 3).

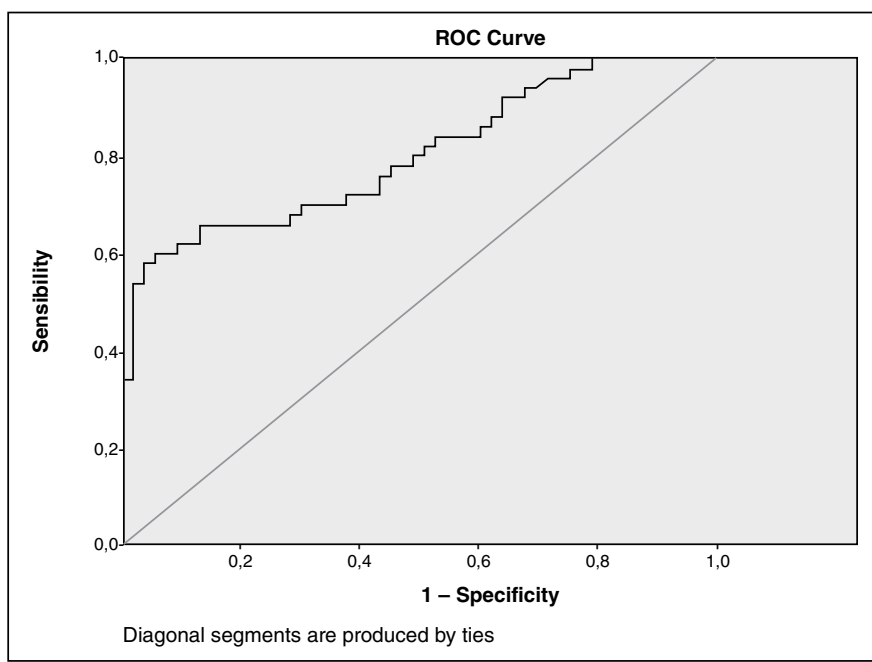

FIGURE 2. ROC curve among Human DNA quantification in the stools of colorectal patients patients and controls

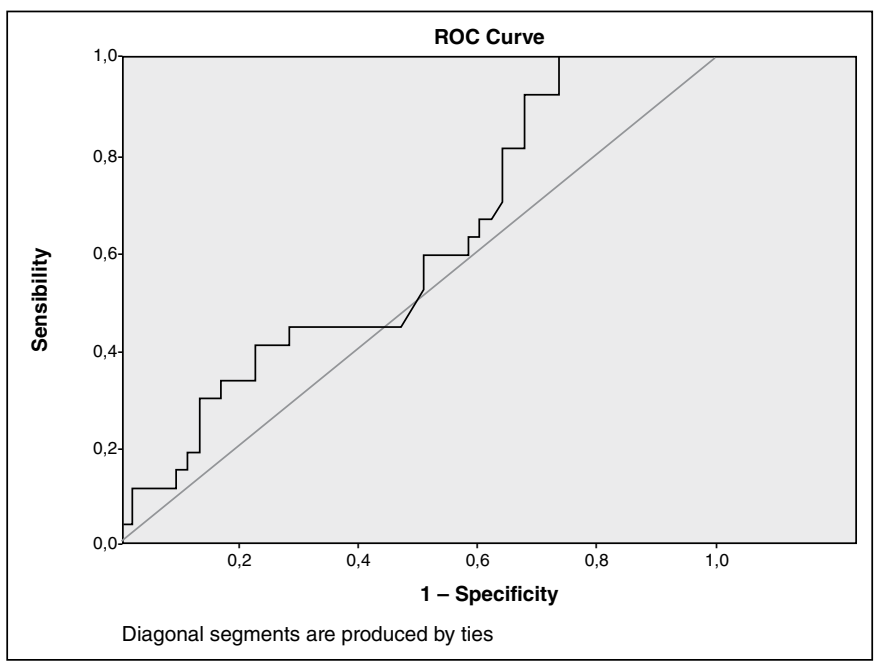

FIGURE 3. ROC curve among Human DNA quantification in the stools of patients with polyps and controls

TABLE 3. Sensitivity, specificity, positive predictive value and negative predictive value of the parameters for fecal human DNA between colorectal cancer and controls and polyps versus controls

\begin{tabular}{lccccc} 
& AUC & $\begin{array}{c}\text { Sensitivity } \\
(\%)\end{array}$ & $\begin{array}{c}\text { Specificity } \\
(\%)\end{array}$ & PPV & PNV \\
\hline CRC x Controls & 0.87 & 66 & 86.8 & 82.5 & 73 \\
Polyps x Controls & 0.41 & 40 & 78 & 50 & 29
\end{tabular}

AUC: area under curve; PPV: predictive positive value, PNV: Predicitve negative value; $C R C$ : colorectal cancer. 


\section{DISCUSSION}

The American Cancer Society recently reported that rates of death from colorectal cancer decreased in $46 \%$ during last years ${ }^{(16)}$. There is good evidence that this better results is a consequence of CRC screening efforts ${ }^{(21)}$. However, new options for early diagnosis should be investigated, since approximately one third of Americans did not adequately fulfills the screening tests ${ }^{(7,18)}$. In Brazil there is not any governmental program for CRC screening and colonoscopy is probably a very expensive exam for Brazilian public health. A noninvasive, low cost method, will have a better compliance by Health authorities.

A possible attractive alternative to the FOBT is the study of DNA alterations in the feces. These noninvasive method may offer advantages over FOBT based screening strategies for the detection of both CRC and critical precursor lesions ${ }^{(11,28)}$.

A problem among the exams did in the stools is the achievement of the samples, three samples of three different days had to be collected for G-FOBT, 1 day for I-FIT or for DNA tests. The stools had to be put in an adequate vial and transported until the laboratory. For DNA tests, the stools had to be frozen and in positive tests, the colonoscopy had to be offered ${ }^{(17)}$. The feces cannot be mixed with the urine.

Regarding stool tests, important advances have been incorporated, including the use of a stabilizing buffer, more discriminating markers, more sensitive analytic methods, automation, which together result in higher sensitivity for the detection of both cancer and advanced precancerous lesions ${ }^{(11)}$.

In the last decade some studies had been done searching for one specific mutation in the stools and found a low sensitivity. Villa et al. ${ }^{(24)}$, found only $29 \%$ of K-ras mutation in the stools of patients with CRC. The association of DNA alterations shown better results, with a higher cost. A multitarget study of DNA in the stools that measure B-actin, mutant K-ras, the aberrant methylation of the genes BMP3 and NDR 4 detected cancer in $98 \%$ of the CRC patients, with a specificity of $90 \%{ }^{(15)}$. A recent study found a higher methylated NDRG4 in the stools of patients with CRC, with a. sensitivity and specificity of 76.2 and $89.15 \%{ }^{(27)}$. Several new attempts had been investigated analyzing biological samples using genetic and epigenetic alterations $^{(14)}$.

In this study we compared the concentration of human and total DNA in the stools of patients with CRC, polyps and controls. We did not find difference among the total DNA in the different groups. In relation to the hDNA, a higher concentration was observed in the stools of patients with CRC compared to the controls and to the patients with polyps. However, no difference was observed between the patients with precancerous disease and patients with normal colonoscopy. The construction of a ROC curve stablished that the best cut off was $0.87 \mathrm{~nm} / \mathrm{mL}$, with a sensitivity of $66 \%$ and a high specificity of $86.8 \%$. These results showed a high positive predictive value. For polyps, we found a lower sensitivity and specificity. The low sensitivity of human fecal DNA in adenomas is probably due to the small size of adenomas as well as the grade of dysplasia. All the adenomas had low or moderate dysplasia. A maximum detection of cancer and precancerous lesions may be achieve using a most sensitive cut off with a lower specificity. This approach is important in screening settings, where we will find more false positive that can be clarified after sent to colonoscopy.

Imperiale et al. ${ }^{(10)}$, found a higher sensitivity and a lower specificity in the study of the concentration of human DNA in the stools of CRC patients compared to the immunochemical FIT. The authors reported that inadequate samples was higher among the study of DNA compared to FIT ( $6.2 \%$ versus $0.3 \%$ respectively). The interval of one year between the exams of the feces has already been established for the immunochemical test FIT ${ }^{(18)}$ but is unknown for DNA quantification.

Patients with CRC had a high index of proliferation cells with a high exfoliation of long DNA fragments in the stools, different from the DNA of apoptotic cells that are of smaller size. A higher concentration of long DNA in the stools had been demonstrated in studies with a small number of patients with CRC. Zou et al. ${ }^{(30)}$, found $44 \%$ sensitivity and $100 \%$ specificity in a study with 20 patients and 18 controls. Boyton et al. ${ }^{(5)}$, also described a high percentage of high molecular DNA in the stools of 22 patients with CRC patients. Calistri et al. ${ }^{(6)}$, also study the long DNA and find a sensitivity and specificity of $82 \%$.

In this study we did not find any difference among the different grades of tumor invasion or stage. Calistri et al.(6), and Lidgard et al..$^{(15)}$, also did not find any difference among the different stages suggesting that it may be a screen method for precocious cancer.

Nielssen et al. ${ }^{(17)}$, suggests an association of screening methods named risk assessment evaluation (RAE), a set of clinical aspects, blood and stool exams that will include proteins, DNA or RNA. The authors believe that such a test may have a higher acceptance among the screening populations, and a high compliance.

A higher concentration of hDNA in the left sided cancer $(P=0.001)$ had been found in this study. Klaasen et al. ${ }^{(13)}$, also found differences between left-sided and right-sided colorectal tumors. Less amount of human DNA in the right colon can occur due to the longer exposure of tumor cells to enzymes that cause degradation of DNA. One other explanation is the bleeding of left sided cancer. Leukocytes with high-molecular-weight DNA may also increase the hDNA into the feces.

New test that include study of DNA methylation, DNA mutations and study of non DNA fecal haemoglobin (Cologuard) had been studied and approved by the FDA. This test may be a promisor noninvasive test for subjects with $\geq 50$ years old, with average risk of colorectal cancer. 
In conclusion a higher concentration of hDNA had been found in colorectal cancer patients, independent of the grade of tumor invasion. Tumors localized in the left side of the colon had higher concentrations of hDNA. On patients with polyps, the sensitivity is lower than for CRC.

The few specific studies, about quantification of human DNA in the stools as a screen method for colorectal cancer, shows that this method is little evaluated and its potential as a marker of CRC had to be studied in a high number of subjects.

This study was funded by FAPESP (The Sao Paulo Research Foundation) number 2009/16618-8.

\section{ACKNOWLEDGEMENTS}

\author{
Aledson Vitor Felipe, PHD and Ermelindo Della Libera \\ Jr MD, PHD.
}

\section{Authors' contributions}

Teixeira Y, Lima JM: acquisition of data and analysis of the tests. Souza MLAPO: analysis of data. Aguiar Jr P: interpretation of data. Silva TD: involved in drafting the manuscript, revising it for important intellectual content. Forones NM: involved in drafting the manuscript, revised it and final approval of the version to be published.

Teixeira Y, Lima JM, Souza MLAPO, Aguiar Jr. P, Silva TD, Forones NM. Quantificação de DNA nas fezes de pacientes com câncer colorretal. Arq Gastroenterol. 2015,52(4):xxx.

RESUMO - Contexto - O câncer colorretal é, mundialmente, uma das principais causas de câncer. A colonoscopia é o melhor método de rastreamento, no entanto a adesão é inferior a 50\%. A quantificação de DNA humano (hDNA) nas fezes pode ser um possível método não invasivo de rastreamento, que é consequência da elevada proliferação e esfoliação de células cancerosas. Objetivo - Quantificar o DNA humano nas fezes de pacientes com câncer colorretal ou pólipos. Métodos - Cinquenta pacientes com câncer colorretal, 26 pólipos e 53 com colonoscopia normal foram incluídas. DNA total e humano foram analisados a partir de fezes congeladas. Resultados - Maior concentração de hDNA nas fezes foi observada em pacientes com câncer colorretal em comparação com controles e pólipos. Pacientes com tumores localizados no cólon esquerdo apresentaram concentrações mais elevadas de hDNA. Não houve diferença entre pólipos e controles. Um nível de corte de $0.87 \mathrm{ng} / \mathrm{mL}$ de DNA humano foi determinado para pacientes com câncer colorretal pela curva ROC, com sensibilidade de $66 \%$ e especificidade de $86,8 \%$. Para pólipos o nível de corte foi de 0,41 , a sensibilidade foi de $41 \%$ e a especificidade de $77,4 \%$. Conclusão - Maior concentração de hDNA foi encontrada em pacientes com câncer colorretal. A quantificação de hDNA das fezes pode ser um método de rastreio do câncer colorretal.

DESCRITORES - Neoplasias colorretais, diagnóstico. Pólipos. DNA. Fezes. 


\section{REFERENCES}

1. Ahlquist DA, Harrington JJ, Burgart LJ, Roche PC. Morphometric analysis of the "mucocellular layer" overlying colorectal cancer and normal mucosa: relevance to exfoliation and stool screening. Hum Pathol. 2000;31(1):51-7.

2. Ahlquist DA, Skoletsky JE, Boynton KA, Harrington JJ, Mahoney DW, Pierceall WE, et al. Colorectal cancer screening by detection of altered human DNA in stool: feasibility of a multitarget assay panel. Gastroenterology. 2000;119(5):1219-27.

3. Ahlquist DA. Molecular Detection of Colorectal Neoplasia. Gastroenterology 2010;138(6):2127-39.

4. Bedi A, Pasricha PJ, Akhtar AJ, Barber JP, Bedi GC, Giardiello FM, et al Inhibition of apoptosis during development of colorectal cancer. Cancer Res. 1995;55(9):1811-6.

5. Boyton KA, Summerhayes IC, Ahlquist DA, Shuber AP. DNA Integrity as a Potencial Marker for Stool-based Detection of Colorectal Cancer. Clin Chem 2003;49(7):1058-65.

6. Calistri D, Rengucci C, Lattunedduy A, Francioniz G, Polifemo AM, Nanni O, et al. Detection of Colorectal Cancer by a Quantitative Fluorescence Determination of DNA Amplification in Stool. Neoplasma. 2004;6(5):536-401.

7. Edwards BK, Ward E, Kohler BA, Eheman C, Zauber AG, Anderson RN, et al. Annual report to the nation on the status of cancer, 1975-2006, featuring ,colorectal cancer trends and impact of interventions (risk factors, screening, and treatment) to reduce future rates. Cancer. 2010;116(3):544-73.

8. Hakama M, Hoff G, Kronborg O, Pahlman L. Screening for colorectal cancer. Acta Oncologica. 2005;44:425-39.

9. Jemal A, Bray F, Center MM, Ferlay J, Ward E, Forman D. Gobal cancer statistics. CA Cancer J Clin. 2011;61(2):69-90.

10. Imperiale TF, Ransohoff DF, Itzkowitz SH, Turnbull BA, Ross ME. Fecal DNA versus Fecal Occult Blood or Colorectal- Cancer Screening in an Avarage-Risk Population. N Engl J Med. 2004;351(26):2704-24

11. Imperiale TF, Ransoff DF, Itzkowitz SH, Levin TR, Lavin P, Lidgard GP, et al. Multitarget Stool DNA Testing for Colorectal-Cancer Screening. N Engl J Med. 2014;370(14):1287-97.

12. Instituto Nacional do Câncer (INCA). [Internet]. [Acessed on April, 2015]. Available from: http://www.inca.gov.br/estimativa/2014/tabelaestados.asp? $\mathrm{UF}=\mathrm{BR} .2014$.

13. Klaassen CHW, Jeunink MAF, Prinsen CFM, Rers JMT, Tan ACITL, Strobbe LJA, Thunnissen FBJM. Quantification of Human DNA in Feces as a Diagnostic Test for the Presence of Colorectal Cancer. Clin Chem. 2003;49(7):1185-7.

14. Lena MD, Travaglio E, Altomare DF. New strategies for colorectal câncer screening. World J Gastroenterol. 2013;19(12):1855-60.
15. Lidgard GP, Domanico MJ, Bruinsma JJ, Light J, Gagrat ZD, Oldham-Haltom RL, et al. Clinical performance of an automated stool DNA assay for detection of colorectal neoplasia. Clin Gastroenterol Hepatol. 2013;11(10):1313-8.

16. Nancy N, Baxter JL, Warren MJ, Barrett TA, Stukel V. Paul DR. Association between colonoscopy and colorectal cancer mortality in a US Cohort according to site of cancer and colonoscopist specialty. J Clin Oncol. 2012;20;30(21):2664-9.

17. Nielsen HJ, Jakobsen KV, Christensen IJ, Brünner N. Screening for colorectal cancer: possible improvements by risk assessment evaluation? Scand J Gastroenterol. 2011;46(11):1283-94.

18. Robertson DJ, Dominitz JA. Stool DNA and Colorectal-Cancer Screening. N Engl J Med. 2014;370:1350-1.

19. Saengow U, Chongsuwiwatvong V, Geater A, Stephen BS. Preferences and Acceptance of Colorectal Cancer Screening in Thailand. Asian Pac J Cancer Prev. 2015;16(6):2269-76.

20. Shanmugathasan M, Jothy S. Apoptosis, anoikis and their relevance to the pathobiology of colon cancer. Pathol Int. 2000;50(4):273-9.

21. Siegel R, Ma J, Zou Z, Jemal A. Cancer statistics, 2014. CA Cancer J Clin. 2014;64(2):104-17.

22. Teoh ML, Puvan R, Cheah PY, Yue Y. Colorectal Cancer Screening: Yield of Faecal Occult Blood Testing. Asian Pacific J Cancer Prev. 2010;11(14):153-6.

23. van Rossum LG, van Rijn AF, Laheij RJ, van Oijen MG, Fockens P, van Krieken $\mathrm{HH}$, et al. Random comparison of guaiac and immunochemical fecal occult blood tests for colorectal cancer in a screening population. Gastroenterology 2008;135(1):82-90.

24. Villa E, Dugani A, Rebecchi AM, Vignoli A, Grottola A, Buttafoco P, et al. Identification of subjects at risk for colorectal carcinoma through a test based on K-ras determination in the stool. Gastroenterology. 1996;110(5):1346-53.

25. Winawer S, Fletcher R, Rex D, Bond J, Burt R, Ferrucci J, et al. Colorectal cancer screening and surveillance: clinical guidelines and rationale-update based on new evidence. Gatroenterology. 2003;124(2):544-60.

26. Winawer SJ. Colorectal cancer screening. Best Practive \& Research Clinical Gastroenterology. 2007;21(6):1031-48.

27. Xiao W, Zhao H, Dong W, Li Q, Zhu J, Li G, et al. Quantitative detection of methylated NDRG4 gene as a candidate biomarker for diagnosis of colorectal cancer. Oncol Lett. 2015;9(3):1383-7.

28. Young GP, Symonds EL, Allison JE, Cole SR, Fraser CG, Halloran SP, et al. Advances in Fecal Occult Blood Tests: the FIT revolution. Advances in Fecal Occult Blood Tests: the FIT revolution. Dig Dis Sci. 2015;60(3):609-22.

29. Zauber AG, Winawer SJ, O'Brien MJ, Landsdorp-Vogelaar I, van Ballegooijen M, Hankey BF. Colonoscopic polypectomy and long-term prevention of colorectal-cancer deaths. N Engl J Med. 2012;366(8):687-96.

30. Zou H, Harrignton JJ, Klatt KK, Ahlquist DA. A sensitive method to quantify human long DNA in stool: relevance to colorectal cancer screening. Cancer Epidemiol Biomarkers Prev. 2006;15(6):1115-9. 